\section{Vegetative and Berry Chemistry Response to Canopy Manipulation and Ethephon in 'Norton' Grapes}

\author{
W. Keith Patterson ${ }^{1}$ \\ Department of Horticulture and Forestry, University of Arkansas, \\ Fayetteville, AR,72701
}

\author{
Bruce W. Zoecklein ${ }^{2}$ \\ Department of Horticulture, Virginia Polytechnic Institute and State \\ University, Blacksburg VA 24061
}

Additional index words. grapevine, growth, Vitis aestivalis

\begin{abstract}
The relationship between canopy manipulation to improve solar penetration and ethephon application was studied on field-grown Vitis aestivalis L. 'Norton' grapevines. Canopy manipulation involved removal of nonfruitful shoots, topping, and application of ethephon $\left(750 \mathrm{mg} \cdot \mathrm{liter}^{-1}\right)$ at two intervals. Vines that were shoot-positioned and topped were not significantly different from control in soluble solids accumulation, but were superior to both ethephon treatments. Potassium levels in grape berries were lower in all treatments than in the control, but malate was significantly reduced only in the 2nd year of the 2-year study. Ethephon successfully controlled vine size and lateral development and thus increased solar penetration into the fruiting zone. Chemical name used: 2-chloroethyl phosphonic acid (ethephon).
\end{abstract}

The grapevine is generally considered a vigorous species developing long and rapidly growing canes. Various pruning and trellising techniques are used to obtain an annual, uniform crop and to maintain the vines in a standard manageable shape. Most of the annual vegetative growth of grape is removed by winter pruning. Thus, the growth potential of the vines is directed to a limited number of growing points, producing vigorous growth of the developing canes. This vigorous growth may induce shading within the canopy, which has been shown to cause early leaf drop and reduced reproductive differentiation in the buds (Jensen et al., 1976).

An excess of vigor and shading has been shown by many workers to produce lowquality fruit. Various researchers (Jensen et al., 1976; Smart, 1982, 1983; Weaver, 1975) have reported that shading within a canopy caused reduced soluble solids concentration, higher malic acid, and reduced anthocyanin contents. Shading also has been implicated in increased $\mathrm{K}$ levels in fruit and juice (Sinton et al., 1978; W.M. Kliewer, personal

Received for publication 10 Feb. 1989. Research conducted at Mt. Pleasant Winery, Augusta, Mo. and Univ. of Missouri, Columbia. The cost of publishing this paper was defrayed in part by the payment of page charges. Under Postal regulations, this paper therefore must be hereby marked advertisement solely to indicate this fact. ${ }^{1}$ Assistant Professor.

${ }^{2}$ Extension Enologist. communication). Potassium ions enter berry cells in direct exchange for protons derived from organic acids (Boulton, 1980a, 1980b, 1980c; Carbonneau and Huglin, 1982). This exchange results in juice and wine that have relatively low titratable acidity and high $\mathrm{pH}$ values (Morris and Cawthon, 1981).

In vigorous vineyards, shading effects commonly are overcome by topping the growing shoots (Lavee, 1981; Peterson and Smart, 1975; Smart, 1983; Weaver, 1975). In some vineyards, this topping is repeated three to four times each season due to the rapid development of lateral buds that are stimulated to grow by the topping (Lavee, 1981; Shulman et al., 1980; Smart, 1982).

Shulman et al. (1980) showed that the growth rate of the lateral shoots depended on their distance from the pruning wound and the severity of the topping. The strongest lateral growth was from the first node below the topping.-Pinching off the apex was enough to induce laterals to develop. Topping of vigorous vines, therefore, may increase the number of growing apices that act as competing sinks to the developing fruit (Koblet, 1977; Lavee, 1981).

Ethephon has been shown to inhibit growth without damaging fruit or foliage (Kliewer et al., 1980; Lavee, 1981; Lavee et al., 1977; Shulman et al., 1980; Szyjewicz and Kliewer, 1983; Weaver, 1975). A clear inhibition of the development of laterals was also reported (Lavee, 1981; Lavee et al.;-1977; Shulman et al., 1980).

The literature contains numerous contradictory reports of berry composition in response to ethephon. There are reports on increases in total soluble solids concentration ( ${ }^{\circ}$ Brix) (Agaoglu, 1981; Jensen et al., 1980; Singh and Chundawat, 1978), increases in the Brix : acid ratio ascribed mainly to decreases in titratable acidity (El Banna and Weaver, 1979; Weaver and Montgomery, 1974; Weaver and Pool, 1971), and no changes in either characteristic (Clore and Fay, 1970; Lavee, 1981; Morris and Cawthon, 1981).

The primary purpose of this investigation was to determine differences in berry composition and vegetative growth in response to canopy manipulation, solar penetration, and ethephon treatment of 'Norton' grapes.

Mature 'Norton' grapevines in a commercial vineyard were used in this study. The vines were spur-pruned and trained to the Geneva double-curtain trellis system. It was a very vigorous vineyard grown on deep loess soils. Spacing was $2.4 \mathrm{~m}$ between vines, with north-south-oriented rows $3.6 \mathrm{~m}$ apart.

A randomized complete-block design was used consisting of four treatments, each treatment replicated four times, with each replicate containing three vines. Border vines were not included in the study.

The 2-year study was conducted using the following treatments: $\mathrm{C}=$ control vines. Standard vineyard practices that employed mechanical topping biweekly, but no shoot positioning, were followed. Mechanical topping consisted of skirting the vines at the soil line to remove the shoot tips that were touch-
Table 1. Effect of ethephon and canopy manipulation on cluster and berry production. ${ }^{z, y}$

\begin{tabular}{|c|c|c|c|c|c|c|}
\hline \multirow[b]{2}{*}{ Treatment ${ }^{x}$} & \multicolumn{2}{|c|}{ Cluster wt (g) } & \multicolumn{2}{|c|}{ Berries/cluster } & \multicolumn{2}{|c|}{ Avg berry wt (g) } \\
\hline & 1983 & 1984 & 1983 & 1984 & 1983 & 1984 \\
\hline$\overline{\mathrm{C}}$ & $110 \mathrm{a}$ & $112 \mathrm{a}$ & $106 \mathrm{a}$ & $104 \mathrm{a}$ & $1.04 \mathrm{c}$ & $1.08 \mathrm{c}$ \\
\hline $\mathrm{SP}$ & $124 \mathrm{~b}$ & $128 c$ & $114 a b$ & $116 \mathrm{~b}$ & $1.08 \mathrm{~d}$ & $1.10 \mathrm{c}$ \\
\hline$S P+E$ & $121 \mathrm{~b}$ & $123 b c$ & $121 \mathrm{~b}$ & $122 \mathrm{~b}$ & $1.00 \mathrm{~b}$ & $1.01 \mathrm{~b}$ \\
\hline$S P+2 E$ & $108 \mathrm{a}$ & $117 \mathrm{ab}$ & $116 a b$ & $123 \mathrm{~b}$ & $0.94 \mathrm{a}$ & 0.95 \\
\hline
\end{tabular}

${ }^{z}$ Means of 12 clusters.

yValues within a column separated by LSD, $P=0.05$.

${ }^{\times} \mathrm{C}=$ control; $\mathrm{SP}=$ shoot positioning, topping, and removal of nonfruitful shoots; $\mathrm{SP}+\mathrm{E}=$ as $\mathrm{SP}$ plus a single application of ethephon; $\mathrm{SP}+2 \mathrm{E}=$ as $\mathrm{SP}+\mathrm{E}$, but with two applications of ethephon 6 weeks apart. 
Table 2. Berry chemistry response to ethepon and canopy manipulation. ${ }^{2 . y}$

\begin{tabular}{|c|c|c|c|c|c|c|c|c|c|c|c|c|}
\hline \multirow[b]{2}{*}{ Treatment } & \multicolumn{2}{|c|}{${ }^{\circ} \mathrm{Brix}$} & \multicolumn{2}{|c|}{$\begin{array}{c}\text { Titratable } \\
\text { acidity }(\mathrm{g} / 100 \mathrm{ml}) \\
\end{array}$} & \multicolumn{2}{|c|}{$\begin{array}{l}\text { Brix : acid } \\
\text { ratio }\end{array}$} & \multicolumn{2}{|c|}{$\begin{array}{c}\text { Malate } \\
(\mathrm{g} / 100 \mathrm{ml})\end{array}$} & \multicolumn{2}{|c|}{$\begin{array}{c}\text { Potassium } \\
(\mathrm{ppm})\end{array}$} & \multicolumn{2}{|c|}{$\mathrm{pH}$} \\
\hline & 1983 & 1984 & 1983 & 1984 & 1983 & 1984 & 1983 & 1984 & 1983 & 1984 & 1983 & 1984 \\
\hline $\mathrm{C}$ & $20.5 \mathrm{a}$ & $21.5 \mathrm{a}$ & $0.570 \mathrm{~b}$ & $0.899 \mathrm{bc}$ & $36.0 \mathrm{a}$ & $23.9 \mathrm{a}$ & $0.400 \mathrm{a}$ & $0.515 \mathrm{a}$ & $2430 a$ & $2625 \mathrm{a}$ & $3.40 \mathrm{a}$ & $3.45 \mathrm{a}$ \\
\hline SP & $20.1 \mathrm{a}$ & $21.8 \mathrm{a}$ & $0.730 \mathrm{a}$ & $1.020 \mathrm{a}$ & $27.5 \mathrm{c}$ & $21.4 b c$ & $0.412 \mathrm{a}$ & $0.392 \mathrm{~b}$ & $1680 \mathrm{c}$ & $1850 \mathrm{~b}$ & $3.35 \mathrm{a}$ & $3.40 \mathrm{a}$ \\
\hline$S P+E$ & $17.6 \mathrm{~b}$ & $18.8 \mathrm{~b}$ & $0.690 \mathrm{~b}$ & $0.946 \mathrm{ab}$ & $25.6 \mathrm{c}$ & $19.9 \mathrm{c}$ & $0.377 \mathrm{a}$ & $0.364 \mathrm{~b}$ & $1740 \mathrm{bc}$ & $1880 \mathrm{~b}$ & $3.30 \mathrm{a}$ & $3.25 \mathrm{~b}$ \\
\hline$S P+2 E$ & $18.0 \mathrm{~b}$ & $18.4 \mathrm{~b}$ & $0.570 \mathrm{~b}$ & $0.844 \mathrm{c}$ & $31.8 \mathrm{~b}$ & $21.8 \mathrm{~b}$ & $0.327 \mathrm{~b}$ & $0.368 \mathrm{~b}$ & $1840 \mathrm{~b}$ & $1800 \mathrm{~b}$ & $3.30 \mathrm{a}$ & $3.50 \mathrm{a}$ \\
\hline
\end{tabular}

${ }^{2}$ Means of 12 vines/treatment.

YValues within a column separated by LSD, $P=0.05$.

${ }^{\times} \mathrm{C}=$ control; $\mathrm{SP}=$ shoot positioning, topping, and removal on nonfruitful shoots; $\mathrm{SP}+\mathrm{E}=$ as $\mathrm{SP}$ plus a single application of ethephon; $S P+2 E=$ as $S P+E$, but with two applications of ethephon 6 weeks apart.

Table 3. Vegetative response to ethephon and canopy manipulation.

\begin{tabular}{lllrr}
\hline \hline & \multicolumn{2}{c}{ Pruning wt $(\mathrm{kg})$} & \multicolumn{2}{c}{ No. lateral } \\
\cline { 2 - 3 } Treatment & 1983 & 1984 & 1983 & 1984 \\
\hline $\mathrm{C}$ & $2.3 \mathrm{a}$ & $6.1 \mathrm{a}$ & $64 \mathrm{a}$ & $-126 \mathrm{a}$ \\
$\mathrm{SP}$ & $1.5 \mathrm{~b}$ & $2.8 \mathrm{~b}$ & $47 \mathrm{a}$ & $77 \mathrm{~b}$ \\
$\mathrm{SP}+\mathrm{E}$ & $1.3 \mathrm{~b}$ & $1.9 \mathrm{c}$ & $50 \mathrm{a}$ & $49 \mathrm{c}$ \\
$\mathrm{SP}+2 \mathrm{E}$ & $0.9 \mathrm{~b}$ & $1.8 \mathrm{c}$ & $24 \mathrm{~b}$ & $21 \mathrm{~d}$ \\
\hline
\end{tabular}

${ }^{2}$ Means of 12 vines.

y Values within a column separated by LSD, $P=0.05$.

${ }^{\mathrm{x}} \mathrm{C}=$ control; $\mathrm{SP}=$ shoot positioning, topping, and removal of nonfruitful shoots; $\mathrm{SP}+\mathrm{E}=$ as $\mathrm{SP}$ plus a single application of ethephon; $S P+2 E=$ as $S P+E$, but with two applications of ethephon 6 weeks apart.

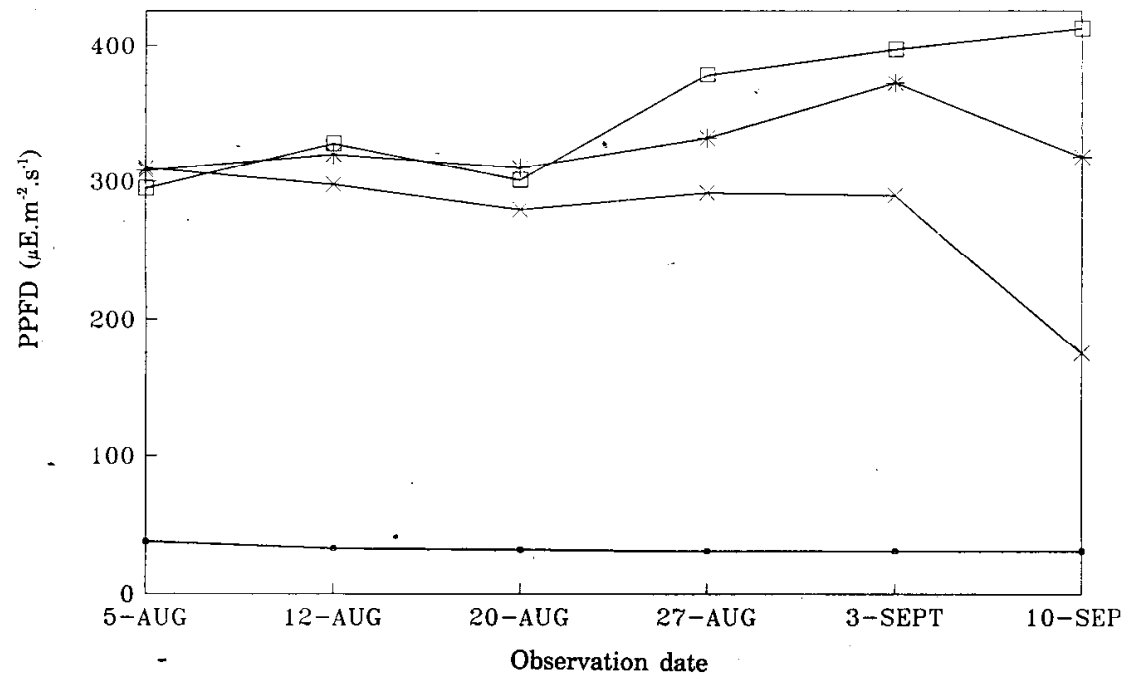

Fig. 1. Influence of shoot positioning and ethephon on solar penetration into the grapevine canopy. $\square=$ Control; $\times=$ shoot positioning, topping, and removal of nonfruitful shoots (SP); * = as SP plus a single application of ethephon; $\square=$ as SP, but with two applications of ethephon 6 weeks apart.

ing the vineyard floor. SP = shoot positioning, topping, and removal of nonfruitful shoots. $\mathrm{SP}+\mathrm{E}=$ as $\mathrm{SP}$ plus a single application of ethephon. $S P+2 E=$ as SP + $\mathrm{E}$, but with two ethephon sprays.

Shoot positioning was begun at time of first ethephon spray and continued weekly to position shoots vertically downward. The concentration of ethephon was $750 \mathrm{mg} \cdot$ liter $^{-1}$ sprayed until run-off (Kliewer et al., 1980; Lavee, 1981). The SP $+E$ and initial SP $+2 \mathrm{E}$ application was 10 days postbloom (Lavee, 1981; Szyjewicz and Kliewer, 1983), with second $\mathrm{SP}+2 \mathrm{E}$ application 6 weeks later.

Solar penetration within the canopy was monitored with a LI-COR Modcl LI-185 B Quantum/Radiometer/Photometer (LI-COR,
Lincoln, Neb.) that measured the photosynthetic photon flux (PPF). Weekly measurements were made at or near solar noon at 10 locations within each treatment during the period of study. The radiometer was oriented upward at the mid-wire of the trellis, which is located $30 \mathrm{~cm}$ below cordon wires and in the middle of the canopy. Data collection began at time of shoot thinning and continued until harvest (Fig. 1).

At harvest, the fruit was transported to the Univ. of Missouri, Columbia, stored at $5 \mathrm{C}$ overnight, and determinations made the following morning. Soluble solids concentration (SSC; ${ }^{\circ}$ Brix) was determined with a temperature-compensated, hand-held refractometer. Titratable acidity, expressed as grams tartaric acid/100 ml juice, was ascertained by titration with $\mathrm{NaOH}$ to thc phenolphthalein end point. Malic acid was determined by enzymatic assay. Potassium levels were resolved on a Fisher Model 975 Plasma Atomcomp (Pittsburgh). Twelve clusters were randomly selected from each treatment, weighed, and the number of berries per cluster determined. All vines were pruned to 30 two-bud spurs 2-6 Feb. the year following harvest. At this time, pruning weights and number of developed lateral shoots per vine were recorded.

Berry development. Per vine yields were similar for all treatments in both years (data not shown). This result agrees with data reported by Wolf et al. (1986) following similar treatments on young 'Chardonnay' grapevines. Bledsoe et al. (1988) also reported no increase in crop weight, cluster weight, or berry weight as a result of leaf removal.

Only SP + E significantly increased the number of berries per cluster relative to the control in 1983 (Table 1). All imposed treatments, however, had more berries per cluster than the control in 1984. The cluster weights were higher in 1984 than in 1983, regardless of vine treatment. The increase for $S P+2 E$ can be attributed to an increase in the number of berries per cluster, as the berry size did not change and was significantly lower than for the other treatments. Higher light levels have increased bud fruitfulness in other studies (Kliewer and Antcliff, 1970; May and Antcliff, 1963) and possibly is the reason for the increase in number of berries per cluster reported here. SP and SP $+E$ produced larger clusters than the control or SP $+2 \mathrm{E}$ in 1983. In 1984, clusters from SP and SP + E were larger than those of the control, while only those of SP were larger than those of SP + $2 \mathrm{E}$. All treatments produced more berries per cluster than the control in 1984. Ethephon appeared to diminish berry size, as the fruit from treated vines was smaller, although ethephon apparently is not translocated into fruit (Weaver et al., 1972). Reduced berry size may have been due to reduccd leaf area of treated vines. Kliewer (1970) found that berry weight was the variable most affected by defoliation treatments.

Berry chemistry. The SSC of fruit from ethephon-treated vines was lower than that for the controls or SP vines in either year (Table 2). Titratable acidity of fruit from SP vines was higher than from all other treatments in 1983, while in 1984, it was higher 
than that from control and $\mathrm{SP}+2 \mathrm{E}$ vines (Table 2). In 1984, SSC and titratable acidity were higher than in the previous season for all treatments. The Brix : acid ratio was highest for the control in both years, indicating a dramatic increase in titratable acidity in the berries of the less-shaded plots. The malate level was reduced only by the $\mathrm{SP}+2 \mathrm{E}$ treatment in the first year, but all were significantly lower than the control in the 2nd year. All treated vines responded with lower $\mathrm{K}$ levels in both years, a positive attribute in grapes for juice and wine. Only $\mathrm{SP}+\mathrm{E}$, however, had a lower $\mathrm{pH}$ than the other treatments in 1984

Vegetative response. Ethephon was very effective in reducing vine size over the control in both years and also was effective in maintaining a smaller canopy than shoot positioning alone in year 2 (Table 3 ). The difference in vine size between SP and the control could be due to the removal of nonfruitful shoots, thus reducing the total vegetation and growing points. There was no significant difference between one and two ethephon applications in total pruning weight produced, although two decreased the number of laterals.

Soluble solids concentration did not increase with shoot manipulation or ethylene application, which does not agree with other published work (Agaoglu, 1981; Jensen et al., 1980; Singh and Chundawat, 1978; Szyjewicz and Kliewer, 1983). This difference may be attributed to the fewer shoots and active growing points in our tests, as expanding leaves exhibit peak photosynthetic activity, declining $\approx 40$ days after unfolding (Kriedemann, 1968; Kriedemann et al., 1970). This hypothesis is supported by earlier experiments on defoliation and shoot removal (Kliewer and Antcliff, 1970; May et al., 1969).

Some authors (El Banna and Weaver, 1979; Weaver and Montgomery, 19743 Weaver and Pool, 1971) have reported increases in the Brix : acid ratio ascribed mainly to decreases in titratable acidity. We obtained a higher level of titratable acidity in SP and SP + E treatments than in the controls and, thus, a lower Brix : acid ratio (Table 2). SP $+2 \mathrm{E}$ and the control yielded similar levels of titratable acidity even though the levels of malate were lower in the fruit of treated vines. Possible reasons for the reduction in malate levels are: 1) exposed fruit of dark cultivars, such as 'Norton', may have a daytime fruit temperature of $15 \mathrm{C}$ higher than shade fruit (Kliewer, 1971), which will result in lower malic acid levels (Smart and Sinclair, 1976) and 2) dense canopies, such as in the control vines, will result in higher malate levels (Carbonneau and Huglin, 1982; Shaulis and Smart, 1974; Smart, 1982).

Results of the vegetative response study agree with earlier reports (Lavee, 1981; Lavee et al., 1977; May et al., 1969; Shulman et al., 1980). All treatments reduced pruning weights, compared to the control. The lower pruning weight of the SP vines probably was due to fewer shoots than in the control, since nonfruitful shoot removal was the only dif- ference between the vines. The differences were more pronounced in 1984, which was a year of more vigorous growth, as exhibited by an increase in vine size of the controls (Table 3).

One of the objectives of this study was to determine if rank vegetative growth could be contained and fruit quality improved in 'Norton' grapes through shoot removal, shoot positioning, and application of ethephon.

The results from this study were erratic and contradictory. The SP treatment resulted in better-balanced fruit with positive responses in malate and $\mathrm{K}$ levels and appeared superior to fruit of the other treatments. The differences in vine size between SP and the control illustrates the large number of nonfruitful shoots produced in this vineyard. Follow-up work is needed to determine if increased solar penetration will increase bud fruitfulness as it has with other species and cultivars (Kliewer et al., 1980; Loomis, 1949; May et al., 1969; Weaver, 1975).

\section{Literature Cited}

Agaoglu, Y.S. 1981. Effects of various application methods of Ethrel on some quality characteristics of grapes. Amer. J. Enol. Vitic. 32(2): 151-153

Bledsoe, A.M., W.M. Kliewer, and J.J. Marois. 1988. Effect of timing and severity of leaf removal on yield and fruit composition of Sauvignon blanc grapevines. Amer. J. Enol. Vitic. 39(1):49-54.

Boulton, R. 1980a. The relationship between total acidity, titratable acidity, and $\mathrm{pH}$ in wine. Amer. J. Enol. Vitic. 31(1):76-80.

Boulton, R. 1980b. General relationship between $\mathrm{K}^{+}, \mathrm{Na}^{+}$, and $\mathrm{pH}$ in grape juice and wine. Amer. J. Enol. Vitic. 31(2):182-186.

Boulton, R. 1980c. A hypothesis for the presence, activity, and role of potassium/hydrogen, adenosine triphosphates in grapevines. Amer. J. Enol. Vitic. 31(3):283-287.

Carbonneau, A. and P. Huglin. 1982. Adaptation of training systems to French regions. Symp. Proc. Grape and Wine Centennial, Davis, Calif. Univ. of California Press. Berkeley.

Clore, W.J. and R.D. Fay. 1970. The effect of pre-harvest application of ethrel in concord grapes. HortScience 5:21-23.

El Banna, G.I. and R.J. Weaver. 1979. Effect of ethephon and gibberellin in maturation of ungirdled Thompson Seedless grapes. Amer. J. Enol. Vitic. 30(1):11-13.

Jensen, F., P. Christensen, H. Andris, F. Swanson, G. Leavitt, and W.L. Peacock. 1980. The effects of ethephon on 'Thomoson Seedless' grapes and raisins. Amer. J. Enol. Vitic. 31(3):257-260

Jensen, F., D. Luvisi, and G. Leavitt. 1976. Effect of pre-bloom shoot treatment on yield and fruit characteristics of Cardinal and Ribier table grapes. Amer. J. Enol. Vitic. 27(2):62-64.

Kliewer, W.M. 1970. Effect of time and severity of defoliation on growth and composition of 'Thompson Seedless' grapes. Amer. J. Enol. Vitic. 21:237-250

Kliewer, W.M. 1971. Effect of day temperatures and light intensity on concentration of malic and tartaric acids in Vitis vinifera L. grapes. J. Amer. Soc. Hort. Sci. 96(3):372-377.

Kliewer, W.M. and A.J. Antcliff. 1970. Influence of defoliation, leaf darkening, and cluster shading on the growth and composition of Sultana grapes. Amer. J. Enol. Vitic. 21:26-36.
Kliewer, W.M., S. Lavee, and M. Vilas. 1980 Effect of ethephon and shoot topping on growth, yield, and composition of Chenin blanc grapevines. Proc. 31st Annual Meeting, Amer. Soc. Enol. Vitic. p. 10-11.

Koblet, W. 1977. Translocation of photosynthate in grapevines. Proc. Intl. Symp. Quality of the Vintage, Cape Town, South Africa. p. 45-51.

Kriedemann, P.E. 1968. Photosynthesis in vine leaves as a function of light intensity, temperature, and leaf age. Vitis 7:213-220.

Kriedemann, P.E., W.M. Kliewer, and J.M. Harris. 1970. Leaf age and photosynthesis in Vitis vinifera $\mathrm{L}$. Vitis 9:97-104.

Lavee, S. 1981. Control of grapevine growth and development, using ethylene releasing substances and some aspects of their action. Amer. J. Enol. Vitic. 32(1):126-131.

Lavee, S., A. Erez, and Y. Shulman. 1977. Control of vegetative growth of grapevines (Vitis vinifera) with ethephon and other growth inhibitors. Vitis 16:89-96.

Loomis, N.H. 1949. The effect of pinching off the terminals on yield and cane growth of 'Champanel' grapes. Proc. Amer. Soc. Hort. Sci. 54:181-182.

May, P. and A.J. Antcliff. 1963. The effect of shading on fruitfulness and yield in the Sultana. J. Hort. Sci. 38:85-94.

May, P., N.J. Shaulis, and A.J. Antcliff. 1969. The effect of controlled defoliation in the Sultana vine. Amer. J. Enol. Vitic. 20:237-250.

Morris, J.R. and D.L. Cawthon. 1981. Effects of ethephon on maturation and post-harvest quality of 'Concord' grapes. J. Amer. Soc. Hort. Sci. 106:293-295.

Peterson, J.R. and R.E. Smart. 1975. Foliage removal effects in 'Shiraz' grapevines. Amer. J. Enol. Vitic. 26(3):119-124.

Shaulis, N.J. and R.E. Smart. 1974. Grapevine canopies: Management, microclimate, and yield responses. Proc. XIXth Intl. Hort. Congress 3:255-265.

Shulman, Y., G. Hirschfeld, and S. Lavee. 1980 Vegetative growth control of six grapevine cultivars by spray application of ethephon. Amer. J. Enol. Vitic. 31(2):288-293.

Singh, I.S. and B.S. Chundawat. 1978. Effect of ethephon in ripening of 'Delight' grapes. HortScience 13:251-253.

Sinton, T.H., C.S. Ough, J.J. Kissler, and A.N. Kasimatis. 1978. Grape juice indicators for prediction of potential wine quality. I. Relationship between crop level, juice and wine composition, and wine sensory rating and scores. Amer. J. Enol. Vitic. 29(4):267-271.

Smart, R.E. 1982. Vine manipulation to improve wine grape quality. Symp. Proc. Grape and Wine Centennial, Davis, Calif. p. 362-37.5.

Smart, R.E. 1983. Canopy microclimate and effects on wine quality. Proc. 5th Austral. Wine Ind. Tech. Conf., Perth, Western Australia. p. 113-132.

Smart, R.E. and T.R. Sinclair. 1976. Solar heating of grape berries and other spherical fruits. Agr. Meteorol. 17:241-259.

Szyjewicz, E. and W.M. Kliewer. 1983. Influence of timing of ethephon application on yield and fruit composition of Chenin blanc grapevines. Amer. J. Enol. Vitic. 34(2):53-56.

Weaver, R.J. 1975. Effect of growth retardant sprays on fruitfulness and cluster development of 'Thompson Seedless'. Amer. J. Enol. Vitic. 26:47-49.

Weaver, R.J., H.A. Abdel-Gawad, and G.C. Martin. 1972. Translocation and persistence of 1,2-14C (2-chloroethyl) phosphonic acid (ethephon) in Thompson Seedless grapes. Physiol. 
Plant. 16:13-16.

Weaver, R.J. and R. Montgomery. 1974. Effect of ethephon on coloring and maturation of wine grapes. Amer. J. Enol. Vitic. 25:39-41.
Weaver, R.J. and R.M. Pool. 1971. Effect of (2chloroethyl) phosphonic acid (ethephon) on maturation of Vitis vinifera. J. Amer. Soc. Hort. Sci. 96:725-727.
Wolf, T.K., R.M. Pool, and L.R. Mattick. 1986. Response of young Chardonnay grapevines to shoot tipping, ethephon, and basal leaf removal. Amer. J. Enol. Vitic. 37:(4):263-267. 